\title{
Local Application of Gentamicin in the Prophylaxis of Perineal Wound Infection After Abdominoperineal Resection: A Systematic Review
}

\author{
G. D. Musters ${ }^{1}$ J. W. A. Burger ${ }^{2}$ - C. J. Buskens ${ }^{1}$ - W. A. Bemelman' ${ }^{1}$. \\ P. J. Tanis ${ }^{1}$
}

Published online: 14 July 2015

(c) The Author(s) 2015. This article is published with open access at Springerlink.com

\begin{abstract}
Background Use of topical antibiotics to improve perineal wound healing after abdominoperineal resection (APR) is controversial. The aim of this systematic review was to determine the impact of local application of gentamicin on perineal wound healing after APR.

Methods The electronic databases Pubmed, EMBASE, and Cochrane library were searched in January 2015. Perineal wound outcome was categorized as infectious complications, non-infectious complications, and primary perineal wound healing.

Results From a total of 582 articles, eight studies published between 1988 and 2012 were included: four randomized controlled trials (RCTs), three comparative cohort studies, and one cohort study without control group. Gentamicin was administered using sponges $(n=3)$, beads $(n=4)$, and by local injection $(n=1)$. There was substantial heterogeneity regarding underlying disease, definition of outcome parameters and timing of perineal wound evaluation among the included studies, which precluded meta-analysis with pooling. Regarding infectious complications, three of six evaluable studies demonstrated a positive effect of local application of gentamicin: one of four RCTs and both comparative cohort studies. Only two RCTs reported on non-infectious complications, showing no significant impact of gentamicin sponge. All three comparative cohort studies demonstrated a significantly higher percentage of primary perineal wound healing after local application of gentamicin beads, but only one out of three evaluable RCTs did show a positive effect of gentamicin sponges.

Conclusion Currently available evidence does not support perineal gentamicin application after APR.
\end{abstract}

\author{
P. J. Tanis \\ P.J.Tanis@amc.nl \\ G. D. Musters \\ G.D.Musters@amc.uva.nl \\ J. W. A. Burger \\ J.Burger@erasmusmc.nl \\ C. J. Buskens \\ C.J.Buskens@amc.uva.nl
}

W. A. Bemelman

W.A.Bemelman@amc.uva.nl

Department of Surgery, Academic Medical Center, University of Amsterdam, Post box 22660, 1105 AZ Amsterdam, The Netherlands

2 Department of Surgery, Erasmus Medical Center/Daniel den Hoed, Post box 5201, 3008 AE Rotterdam, The Netherlands 


\section{Introduction}

Impaired perineal wound healing after abdominoperineal resection (APR) is a clinically significant problem. Perineal wound infection, wound dehiscence, and deep pelvic abscess are frequently encountered complications, which often require intensive and long-lasting wound care and interfere with quality of life. Furthermore, modified approaches for distal rectal cancer have increased the incidence of perineal wound problems after APR, especially the use of neo-adjuvant radiotherapy [1]. Surgical site infections, like perineal wound infection, may result in prolonged hospitalization, readmission, increase in health care costs, and even an increase in mortality [2]. The cornerstone in the prevention of wound infection is the use of systemic and/or oral prophylactic antibiotics. Despite prophylactic antibiotics, perineal wound infection has been reported to occur in more than half of the patients who undergo an APR after neo-adjuvant radiotherapy for rectal cancer [3]. For the antibiotics to be effective, a high antibiotic concentration at the designated site is warranted. However, systemic administration hardly effects perineal wound healing. This is most likely due to dead space with retention of fluids and surgically impaired blood supply. Perineal application leads to high local concentrations with low serum levels and hence low systemic adverse reactions [4]. In general, local gentamicin application is regarded as safe, easy to use, and inexpensive [5]. However, there is still no consensus on the clinical value of topical gentamicin to improve perineal wound healing in patients undergoing APR. Therefore, we conducted a systematic review of the literature on the effect of local gentamicin in preventing perineal wound infection and improving perineal wound healing after APR.

\section{Methods}

\section{Search strategy}

All studies evaluating the impact of local application of gentamicin on perineal wound healing after APR were considered eligible. Inclusion was not restricted to study design (i.e., randomized controlled trial (RCT), prospective or retrospective cohort study (with or without control group), and underlying disease (i.e., rectal cancer, anal cancer, and inflammatory bowel disease). Animal studies, systematic reviews, non-English articles, case series $(<5$ patients), and congress abstracts were excluded. Studies were identified by searching electronic databases and scanning of reference lists. This search was applied in PubMed (1971-2015), EMBASE (1982-2015), and Cochrane library (2005) databases in January 2015. The following medical subject heading (MESH) terms were used; gentamicin, aminoglycosides, anti-bacterial agents, perineum, abdomen, colorectal surgery, surgical procedures operative, and general surgery. Other search terms were abdominal perineal resection, abdominoperineal resection, abdominoperineal excision, abdominal perineal excision, perineum surgery, perineal surgery, gentamicin, gentamycin, aminoglycoside antibiotics, and local antibiotics. No language or publication date restrictions were applied. The candidate publication titles and abstracts were screened to exclude non-related publications. Secondly, the full text of the remaining manuscripts was read to determine whether they were eligible for inclusion.

\section{Validity assessment and assessment of eligibility}

Methodological quality and risk of bias were assessed for the included studies. For cohort studies, the Newcastle Ottawa quality assessment scale for cohort studies was used to assess risk of bias [6]. The quality items scored were as follows: representativeness of the exposed cohort, selection of the non-exposed cohort, ascertainment of exposure, the absence of outcome of interest at the start of the study, validity of the design or analysis, assessment of outcome, duration of follow-up, and lost to follow-up. For RCTs, the Jadad scoring system was used to assess the risk of bias [7].

\section{Data extraction and data analysis}

Data were extracted from the included studies by two independent investigators (GM, PT). Disagreements were resolved by discussion between the two reviewers. For each article, the following data were collected: year of publication, study design, number of patients, underlying disease, comorbidities, type of APR, neo-adjuvant radiotherapy, perineal closure technique, perineal drainage, systemic antibiotic use, administration method and dosage of locally applied gentamicin, definitions of outcome parameters, follow-up period, type and incidence of perineal wound complications, primary perineal wound healing rate, reoperation rate, and hospital stay. Meta-analysis was not intended because of the heterogeneity among studies regarding study population, variety in gentamicin application, and non-uniform definitions of outcome parameters.

\section{Results}

The systematic search resulted in a total of 582 articles. After removal of duplicates among the different databases, 527 articles remained. After screening of publication titles 
and abstracts, 17 publications were retrieved for full text review. Of these 17 publications, 10 studies were excluded, because gentamicin was not placed in the perineal wound $(n=3)$ [8-10], no separate data for perineal and abdominal wound outcome were provided $(n=4)$ [11-14], surgery was not an APR procedure $(n=1)$ [15], use of bacitracin spray instead of gentamicin $(n=1)$ [16], and the type of local antibiotic was not described $(n=1)$ [17]. One additional study was included after crosschecking reference lists of the included studies. In total, eight studies were included of which four were RCTs, three were comparative cohort studies, and the remaining study was a non-comparative cohort study. After exclusion of patients who underwent non-APR surgery from two cohort studies [18, 19], a total number of 602 patients were included in this systematic review. The risk of bias of the included studies is displayed in "Appendix".

\section{Patient characteristics}

Patient characteristics of each included study are displayed in Table 1. APR was performed for cancer in $68 \%$ ( $n=381$ ) of the patients, which was primary rectal cancer in $82 \%$ ( $n=311$; five studies) [19-23], anal cancer in $4 \%$ ( $n=15$; two studies) [20,23], locally recurrent rectal or anal cancer in $1 \%$ ( $n=4$; one study) [20], sarcoma in one patient [20], and unspecified type of cancer in $13 \%(n=50$; two studies) of the patients $[16,24]$. In three studies, patients with inflammatory bowel disease were also included with a specified number of patients in two studies (total $n=46$ ) $[18,20,24]$. In the remaining patients, APR was performed for incontinence [20], villous adenoma [24], or unspecified diseases [18, 25]. Comorbidities related to risk of wound infection were described in two studies $[21,22]$. Use of neoadjuvant radiotherapy was described in three studies and was given to $21 \%$ ( $n=115$ ) of the included patients [20-22]. Type of neo-adjuvant radiotherapy was only specified in one study $(5 \times 5 \mathrm{~Gy})$ [21]. One study described prior pelvic radiotherapy in four patients [20].

\section{Surgery and prophylactic antibiotics}

The different types of surgery being performed in the included studies are specified in Table 1. None of the studies described the use of an omental plasty. Primary perineal wound closure was performed in all studies, of which four studies mentioned closure in multiple layers [20-23]. Routine pelvic drainage was described in seven studies [18, 19, 21-25], and a perineal drain was selectively placed in one study [19]. Type of drainage differed among study groups in one study, with irrigation-suction drainage in the control group, and either continuous or intermittent drainage in the local gentamicin beads group [25].
Considering the type of local administration of gentamicin at the perineal wound, a collagen carrier was used in three studies [20-22], gentamicin beads were used in four studies [18, 19, 23, 25], and gentamicin was locally injected in one study (Table 2) [24]. Dosage of locally applied gentamicin was provided in four studies. A total dose of $210 \mathrm{mg}$ [22], $200 \mathrm{mg}$ [20], and $160 \mathrm{mg}$ [24] was used in three studies. In the remaining study, the concentration of gentamicin was measured in the wound fluid with a mean value of $138.1 \mu \mathrm{g} / \mathrm{l}(n=7$, standard deviation 58.4) at day one post-operatively [23]. Four studies described placement of the local antibiotic in the sacral cavity [21-23, 25], while a more superficial application in the perineal wound was reported in the other four studies [18-20, 24]. Seven of eight studies described routine use of different regimens of prophylactic pre-operative antibiotics, and five studies also continued prophylactic antibiotics post-operatively, only in a subgroup of patients in one of these five studies (Table 2).

\section{Perineal wound outcome}

Perineal wound outcome parameters were defined in six out of eight included studies, all being different among these six studies (Table 3). Time points for wound evaluation were provided in five studies, which were also not uniform.

Perineal wound outcome was categorized as infectious complications, non-infectious complications, and primary wound healing for the purpose of this review (Table 3). Regarding infectious complications, three of six evaluable studies demonstrated a positive effect of local application of gentamicin. This significant difference was found in one out of four RCTs [22], and both comparative cohort studies $[21,25]$. The impact on infectious complications was found in two out of three studies using gentamicin sponge [21, $22]$ and in one out of two studies using gentamicin beads [25].

Regarding non-infectious complications (i.e., seroma, hematoma, and dehiscence without infection), only two studies uniformly reported this outcome parameter. These two RCTs did not report a significant impact of gentamicin sponge on this perineal wound outcome parameter [20, 22]. One additional comparative cohort study reported a significant difference in the incidence of persistent perineal fistula in favor of gentamicin beads [25], although a fistula may be also considered as a long-term consequence of an initial infectious problem.

Primary perineal wound healing was the most consistently reported outcome parameter among seven included studies, including six comparative studies. However, the RCT of Collin et al. demonstrates that this outcome parameter is highly dependent on the time point of 


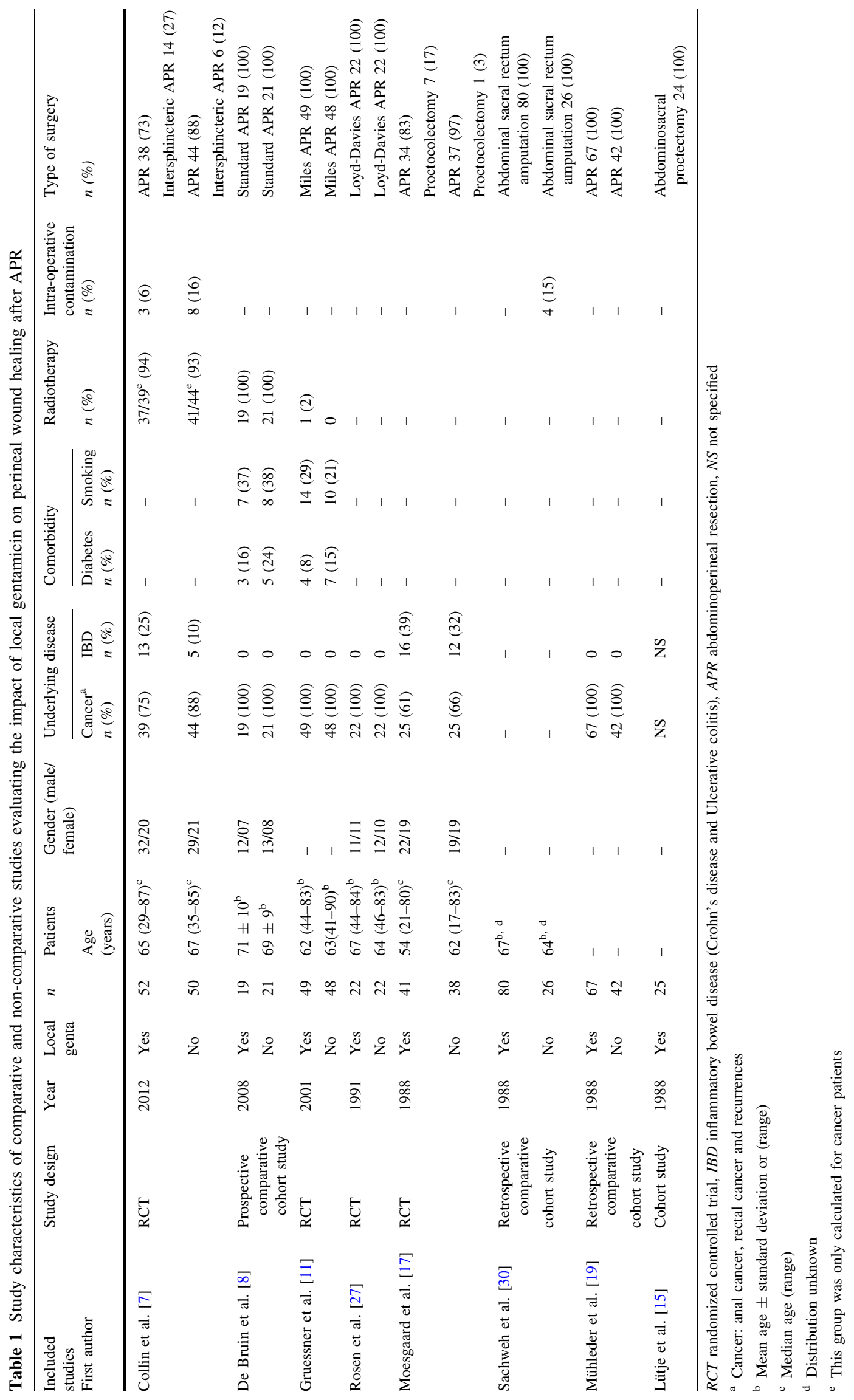


Table 2 Use of local and systemic antibiotics in patients undergoing APR with primary perineal closure

\begin{tabular}{|c|c|c|c|c|c|c|}
\hline \multirow{2}{*}{$\begin{array}{l}\text { Included } \\
\text { studies } \\
\text { First author }\end{array}$} & \multirow[t]{2}{*}{$n$} & \multicolumn{3}{|c|}{ Local antibiotics } & \multicolumn{2}{|l|}{ Systemic antibiotics } \\
\hline & & $\begin{array}{l}\text { Local } \\
\text { (Yes/no) }\end{array}$ & Type & Location & Pre-operative & Post-operative \\
\hline \multirow[t]{2}{*}{$\begin{array}{l}\text { Collin et al. } \\
\text { [7] }\end{array}$} & 52 & Yes & $\begin{array}{l}\text { Genta sulfate sponge } 2.0 \mathrm{mg} / \mathrm{m}^{2} \\
\text { (Collatamp) }\end{array}$ & $\begin{array}{l}\text { Perineal } \\
\text { wound }\end{array}$ & Prophylaxis not specified & $\begin{array}{l}\text { Not specified } \\
n(\%): 11(21)\end{array}$ \\
\hline & 50 & No & - & - & Prophylaxis not specified & $\begin{array}{l}\text { Not specified } \\
n(\%): 11(22)\end{array}$ \\
\hline \multirow[t]{2}{*}{$\begin{array}{l}\text { De Bruin } \\
\text { et al. [8] }\end{array}$} & 19 & Yes & $\begin{array}{l}\text { Genta sponge (Garacol), } 3 \text { per } \\
\text { patient }\end{array}$ & $\begin{array}{l}\text { Sacral } \\
\text { cavity }\end{array}$ & $\begin{array}{l}\text { Augmentin } 1 \times 1000 / \\
200 \mathrm{mg}\end{array}$ & - \\
\hline & 21 & No & - & - & $\begin{array}{l}\text { Augmentin } 1 \times 1000 / \\
200 \mathrm{mg}\end{array}$ & - \\
\hline \multirow[t]{2}{*}{$\begin{array}{l}\text { Gruessner } \\
\text { et al. [11] }\end{array}$} & 49 & Yes & $\begin{array}{l}\text { Genta sponge (Septocoll), } 3 \text { per } \\
\text { patient }\end{array}$ & $\begin{array}{l}\text { Sacral } \\
\text { cavity }\end{array}$ & $\begin{array}{l}\text { Cefa } 1 \times 2 \mathrm{~g} \text {, metro } \\
1 \times 500 \mathrm{mg}\end{array}$ & - \\
\hline & 48 & No & - & - & $\begin{array}{l}\text { Cefa } 1 \times 2 \mathrm{~g} \text {, metro } \\
1 \times 500 \mathrm{mg}\end{array}$ & - \\
\hline \multirow[t]{2}{*}{$\begin{array}{l}\text { Rosen et al. } \\
{[27]}\end{array}$} & 22 & Yes & $\begin{array}{l}\text { Genta-PMMA, } 30 \text { beads, } 1 \text { chain } \\
\text { per patient }\end{array}$ & $\begin{array}{l}\text { Sacral } \\
\text { cavity }\end{array}$ & $\begin{array}{l}\text { Cefa } 1 \times 2 \mathrm{~g} \text {, metro } \\
1 \times 500 \mathrm{mg}\end{array}$ & $\begin{array}{l}\text { Cefa } 2 \times 2 \mathrm{~g} \text {, metro } \\
2 \times 500 \mathrm{mg} \text {; day of operation }\end{array}$ \\
\hline & 22 & No & - & - & $\begin{array}{l}\text { Cefa } 1 \times 2 \mathrm{~g} \text {, metro } \\
1 \times 500 \mathrm{mg}\end{array}$ & $\begin{array}{l}\text { Cefa } 2 \times 2 \mathrm{~g} \text {, metro } \\
2 \times 500 \mathrm{mg} \text {; day of operation }\end{array}$ \\
\hline \multirow[t]{2}{*}{$\begin{array}{l}\text { Moesgaard } \\
\text { et al. [17] }\end{array}$} & 41 & Yes & $\begin{array}{l}\text { Injection } 160 \mathrm{mg} \text { genta/400 mg } \\
\text { metro }\end{array}$ & $\begin{array}{r}\text { Perineal } \\
\text { wound }\end{array}$ & $\begin{array}{l}\text { Genta } 1 \times 80 \mathrm{mg} \text {, metro } \\
1 \times 500 \mathrm{mg}\end{array}$ & $\begin{array}{l}\text { Genta } 3 \times 80 \mathrm{mg} \text {, metro } \\
3 \times 500 \mathrm{mg} ; 2 \text { days }\end{array}$ \\
\hline & 38 & No & - & - & $\begin{array}{l}\text { Genta } 1 \times 80 \mathrm{mg} \text {, metro } \\
1 \times 500 \mathrm{mg}\end{array}$ & $\begin{array}{l}\text { Genta } 3 \times 80 \mathrm{mg} \text {, metro } \\
3 \times 500 \mathrm{mg} ; 2 \text { days }\end{array}$ \\
\hline \multirow[t]{2}{*}{$\begin{array}{l}\text { Sachweh } \\
\text { et al. [30] }\end{array}$} & 80 & Yes & $\begin{array}{l}\text { Genta-PMMA, } 30 \text { beads, } 2 \text { chains } \\
\text { per patient }\end{array}$ & $\begin{array}{l}\text { Sacral } \\
\text { cavity }\end{array}$ & - & - \\
\hline & 26 & No & - & - & - & - \\
\hline \multirow[t]{2}{*}{$\begin{array}{l}\text { Mühleder } \\
\text { et al. [19] }\end{array}$} & 67 & Yes & Genta-PMMA, 1 chain per patient & $\begin{array}{r}\text { Perineal } \\
\text { wound }\end{array}$ & $\begin{array}{l}\text { Paro } 4 \times 500 \mathrm{mg} \text {, metro } \\
3 \times 500 \mathrm{mg} \text { orally }\end{array}$ & Metro $3 \times 500 \mathrm{mg} ; 3$ days \\
\hline & 42 & No & - & - & - & - \\
\hline $\begin{array}{l}\text { Lütje et al. } \\
{[15]}\end{array}$ & 25 & Yes & $\begin{array}{l}\text { Genta PMMA } 30 \text {-beads } \\
\text { (Septopal), } 1 \text { chain per patient }\end{array}$ & $\begin{array}{l}\text { Perineal } \\
\text { wound }\end{array}$ & Latamoxef $1 \times 2 \mathrm{~g}$ & $\begin{array}{l}\text { Latamoxef } 1 \times 2 \mathrm{~g} 12 \mathrm{~h} \text { after } \\
\text { incision }\end{array}$ \\
\hline
\end{tabular}

Cefa cefazolin, Metro metronidazole, Paro paromomycin, Genta gentamicin

evaluation, ranging from $82 \%$ after 7 days to $47 \%$ after 1 month in the control group [20]. All three comparative cohort studies demonstrated a significantly higher percentage of primary perineal wound healing after local application of gentamicin [19,21, 25], but only one out of three evaluable RCTs did show a positive effect of local gentamicin [23]. The positive effect of local gentamicin on primary wound healing was found in one out of three studies using sponges [21] and in all three comparative studies using beads $[19,23,25]$. Significant improvements in perineal wound outcome after local gentamicin were only observed in homogenous cancer populations, while the two RCTs containing subgroups of patients with IBD were both negative $[20,24]$.

\section{Reoperation and hospital stay}

The reoperation rate for perineal wound infection was described in three studies and ranged between 2 and $5 \%$ for the local application of gentamicin and ranged between 0 and $9 \%$ when no topical antibiotics were applied [20, 22, 23]. Hospital stay was described in six studies (Table 3) [18, 20, 21, 23-25]. Out of five comparative studies, three studies reported a significant reduction in hospital stay $(p<0.05)[21,23,25]$. The mean reduction in hospital stay was at least 7 days [21, 23, 25].

\section{Discussion}

The present systematic review of the literature on perineal application of gentamicin after APR reveals that only a limited number of randomized and comparative cohort studies have been published, which are all of relatively low quality. Five of eight included studies were published more than 20 years ago. Most RCTs did not perform a power calculation and can be considered underpowered. Substantial heterogeneity was observed among the studies regarding 


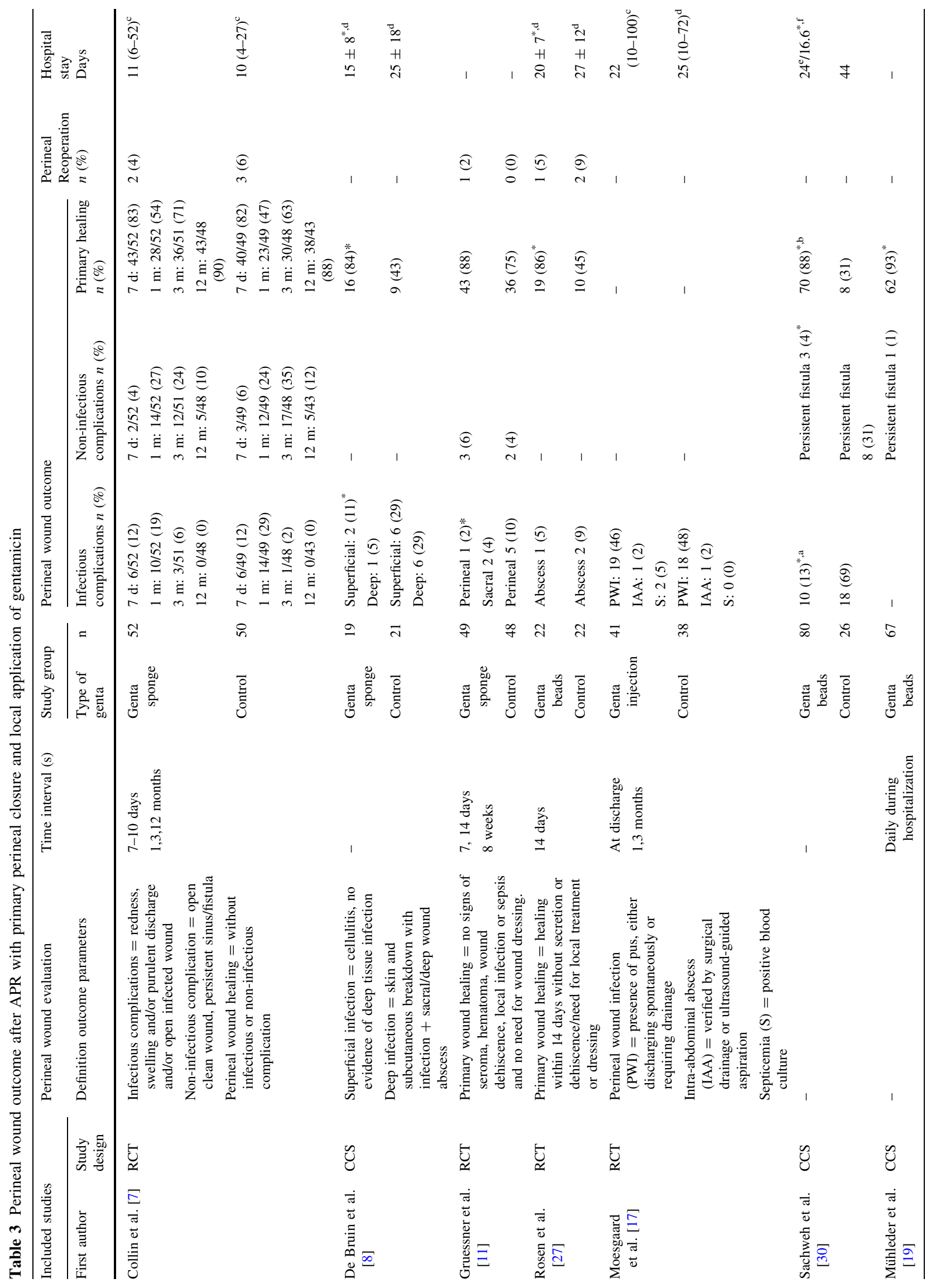




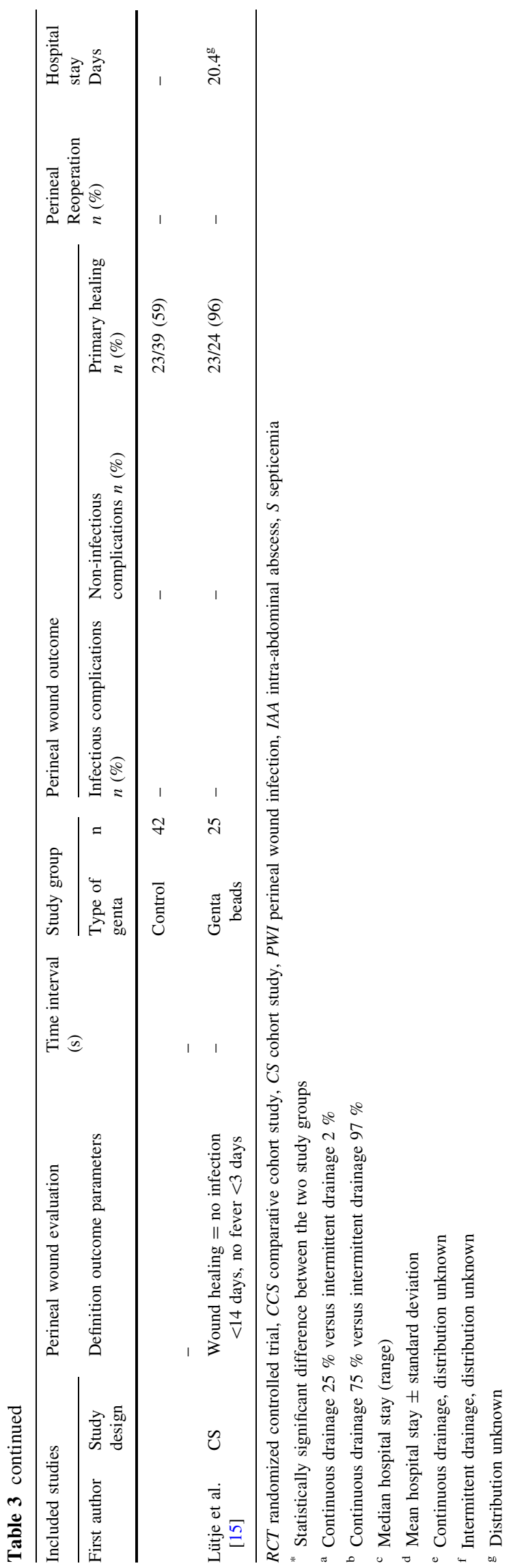

underlying disease, surgical techniques, type of administration of gentamicin, antibiotic dosage, and peri-operative use of systemic antibiotics, definitions of outcome parameters, and timing of perineal wound evaluation. In addition, the non-randomized comparative studies have a substantial risk of bias. Taking all these methodological shortcomings in mind, we conclude that there is no convincing evidence for routine perineal application of gentamicin after APR. Statistically significant differences in favor of local gentamicin were mainly observed in comparative cohort studies, while the majority of RCTs were negative for both wound infection and primary wound healing.

In contrast to the present study, a recent systematic review showed that local application of gentamicin in all clean and clean contaminated wounds significantly reduces surgical site infections [26]. For patients undergoing colorectal surgery, several studies reported a positive effect of local gentamicin $[10,13]$. However, gentamicin was mostly applied to the abdominal wound in these studies, without reporting on the use of topical antibiotics at the perineal wound with corresponding outcome. There are several potential reasons for a difference in wound healing between abdominal and perineal wounds, for example, with regard to the degree of bacterial contamination, tension on wound edges, and the received radioactivity dose in case of neo-adjuvant treatment [27, 28]. In addition, fluid may collect in the dead space above the closed perineum, and may become secondarily infected, with subsequent drainage through the perineum. The abdominal pressure on the perineal wound after (partially) resecting the pelvic floor may also negatively influence perineal wound healing. Because of these differences, our systematic review specifically focused on the perineal wound.

There are several patients and surgery-related factors influencing perineal wound healing after APR. Although the majority of patients were diagnosed with cancer, inflammatory bowel disease was also included in three studies. Inflammatory bowel disease patients significantly differ from cancer patients regarding perineal wound healing due to malnutrition, chronic pelvic inflammation, use of immunosuppressive medication, and pre-existing perineal fistulas and sinuses [29]. On the other hand, the use of preoperative radiotherapy in rectal cancer patients may affect wound healing significantly [1]. Surgical techniques may also influence the occurrence of perineal wound infection and subsequent perineal wound healing. The omentum, for instance, is a major contributor to the local immune response and has the ability to promote angiogenesis [30, 31]. Therefore, placing an omental plasty in the pelvic cavity has been suggested to improve primary perineal wound healing [32]. Besides an omental plasty, several types of musculocutaneous or perforator flaps can be used for closure of the pelvic defect in selected patients undergoing extensive resection (i.e., exenterations) or salvage surgery for anal 
cancer [33-35]. None of the patients in the included studies underwent flap reconstruction, and the use of omental plasty was not specified. Therefore, the additive value of local gentamicin in combination with an autologous tissue flap or omental plasty is unknown. Furthermore, none of the included studies described laparoscopic surgery, the use of vessel sealing equipment, or patient positioning which have been shown to be related to blood loss, operative time, and risk of surgical site infection. These procedural characteristics may be of influence on perineal wound healing and may hamper extrapolation of results of the present systematic review to current clinical practice $[24,36]$.

Among the different application techniques, sponges, beads, and injection differ in local gentamicin concentration and release over time [4]. Besides differences in local antibiotic concentration, the collagen from which the gentamicin is delivered can have an influence on perineal wound healing itself [37]. This is most likely due to faster hemostasis and the protective effect on seroma and hematoma formation, which ultimately could affect primary perineal wound healing [37].

Gentamicin is most effective against gram-negative bacteria and some gram-positive bacteria, with the exception of anaerobe bacteria. Nelson et al. described in a systematic review of 182 RCTs that the addition of antibiotics against anaerobe bacteria in colorectal surgery reduces surgical site infections [38]. Based on these data, an antibiotic that is effective against anaerobic bacteria is currently most often being added as pre-operative prophylaxis [39]. However, antibiotics effective against anaerobe bacteria are most often not locally applied in a sustained matter and combined with gentamicin. Therefore, the local application of gentamicin in combination with an antibiotic targeting anaerobe bacterium might enhance the effectiveness against perineal wound problems.

In conclusion, a restricted number of low-quality randomized and non-randomized studies do not convincingly show a positive effect of local gentamicin on perineal wound infection or primary wound healing rate. APR for benign and malignant disease is essentially different, and treatment of distal rectal cancer has changed significantly since publication of most of the included studies. This underlines the need for new RCTs on locally applied gentamicin in more representative and homogeneous patient groups. At present, available literature does not support the routine use of local gentamicin application for perineal wound healing following APR.

\section{Compliance with Ethical Standards}

Conflict of interest None.

Open Access This article is distributed under the terms of the Creative Commons Attribution 4.0 International License (http://crea tivecommons.org/licenses/by/4.0/), which permits unrestricted use, distribution, and reproduction in any medium, provided you give appropriate credit to the original author(s) and the source, provide a link to the Creative Commons license, and indicate if changes were made.

\section{Appendix}

See Table 4.

Table 4 Assessment risk of bias

\begin{tabular}{|c|c|c|c|c|c|}
\hline \multirow[t]{2}{*}{ Included Studies } & \multirow[t]{2}{*}{ Jadad et al. [14] $(0-5)$} & \multicolumn{4}{|c|}{ Newcastle Ottawa quality assessment scale [38] cohort studies } \\
\hline & & Selection $(0-4)$ & Comparability $(0-2)$ & Outcome $(0-3)$ & Total $(0-9)$ \\
\hline Collin et al. [7] & 2 & - & - & - & - \\
\hline De Bruin et al. [8] & - & 2 & - & 1 & 3 \\
\hline Gruessner et al. [11] & 1 & - & - & - & - \\
\hline Rosen et al. [27] & 1 & - & - & - & - \\
\hline Lütje et al. [15] & - & 1 & - & 1 & 2 \\
\hline Sachweh et al. [30] & - & 1 & - & 1 & 2 \\
\hline Mühleder et al. [19] & - & 1 & - & 1 & 2 \\
\hline Moesgaard et al. [17] & 2 & - & - & - & - \\
\hline
\end{tabular}




\section{References}

1. Musters GD, Buskens CJ, Bemelman WA et al (2014) Perineal wound healing after abdominoperineal resection for rectal cancer: a systematic review and meta-analysis. Dis Colon Rectum 57(9):1129-1139

2. Perencevich EN, Sands KE, Cosgrove SE et al (2003) Health and economic impact of surgical site infections diagnosed after hospital discharge. Emerg Infect Dis 9(2):196-203

3. Nissan A, Guillem JG, Paty PB et al (2001) Abdominoperineal resection for rectal cancer at a specialty center. Dis Colon Rectum 44(1):27-35

4. Ruszczak Z, Friess W (2003) Collagen as a carrier for on-site delivery of antibacterial drugs. Adv Drug Deliv Rev 55(12):1679-1698

5. Friberg O, Dahlin LG, Levin LA et al (2006) Cost effectiveness of local collagen-gentamicin as prophylaxis for sternal wound infections in different risk groups. Scand Cardiovasc J 40(2):117-125

6. Wells GA, Shea B, O'Connell D, et al (2014) The NewcastleOttawa Scale (NOS) for assessing the quality of nonrandomised studies in meta-analyses. Research institute. http://www.ohri.ca/ programs/clinical_epidemiology/oxford.asp. Accessed 1 Jan 2015

7. Jadad AR, Moore RA, Carroll D et al (1996) Assessing the quality of reports of randomized clinical trials: is blinding necessary? Control Clin Trials 17(1):1-12

8. Bennett-Guerrero E, Pappas TN, Koltun WA et al (2010) Gentamicin-collagen sponge for infection prophylaxis in colorectal surgery. N Engl J Med 363(11):1038-1049

9. Pochhammer J, Zacheja S, Schaffer M (2015) Subcutaneous application of gentamicin-collagen implants as prophylaxis of surgical site infections in laparoscopic colorectal surgery: a randomized, double-blinded, three-arm trial. Langenbecks Arch Surg $400(1): 1-8$

10. Rutten HJ, Nijhuis PH (1997) Prevention of wound infection in elective colorectal surgery by local application of a gentamicincontaining collagen sponge. Eur J Surg Suppl 578:31-35

11. Aubrey DA, Jenkins NH, Morgan WP et al (1986) The use of gentamicin-PMMA chains in abdominal surgery: a pilot study of prophylaxis against wound infection. Pharmatherapeutica 4(8):536-540

12. Morawiec Z, Pawlak M, Kolacinska A et al (2012) Local antibiotic therapy in rectal cancer surgery. Pol Przegl Chir 84(12):613-617

13. Nowacki MP, Rutkowski A, Oledzki J et al (2005) Prospective, randomized trial examining the role of gentamycin-containing collagen sponge in the reduction of postoperative morbidity in rectal cancer patients: early results and surprising outcome at 3-year follow-up. Int J Colorectal Dis 20(2):114-120

14. Spence RA, Anderson JR, Parks TG (1984) The use of gentamicin-PMMA chains in colorectal surgery. $\mathrm{Br} \mathrm{J}$ Clin Pract 38(7-8):252-254

15. Brehant O, Sabbagh C, Lehert P et al (2013) The gentamicincollagen sponge for surgical site infection prophylaxis in colorectal surgery: a prospective case-matched study of 606 cases. Int J Colorectal Dis 28(1):119-125

16. Irvin TT, Goligher JC (1975) A controlled clinical trial of three different methods of perineal wound management following excision of the rectum. Br J Surg 62(4):287-291

17. Meyer L, Bereuter M, Marusch F et al (2004) Perineal wound closure after abdomino-perineal excision of the rectum. Tech Coloproctol 8(Suppl 1):s230-s234

18. Lutje HC, Penschuck C, Aydin V (1988) Local antibiotic treatment of soft-tissue infections with gentamicin-PMMA chains. Reconstr Surg Traumatol 20:112-119

19. Muhleder H, Togel K, Urbanek $\mathrm{H}$ et al (1988) Gentamicinpolymethylmethacrylate chains in colonic surgery. Reconstr Surg Traumatol 20:105-111
20. Collin A, Gustafsson U-M, Smedh K et al (2013) Effect of local gentamicin-collagen on perineal wound complications and cancer recurrence after abdominoperineal resection: a multicentre randomized controlled trial. Colorectal Dis 15(3):341-346

21. De Bruin AFJ, Gosselink MP, Wijffels NAT et al (2008) Local gentamicin reduces perineal wound infection after radiotherapy and abdominoperineal resection. Tech Coloproctol 12(4):303-307

22. Gruessner U, Clemens M, Pahlplatz PV et al (2001) Improvement of perineal wound healing by local administration of gentamicinimpregnated collagen fleeces after abdominoperineal excision of rectal cancer. Am J Surg 182(5):502-509

23. Rosen HR, Marczell AP, Czerwenka E et al (1991) Local gentamicin application for perineal wound healing following abdominoperineal rectum excision. Am J Surg 162(5):438-441

24. Moesgaard F, Lykkegaard NM (1988) Failure of topically applied antibiotics, added to systemic prophylaxis, to reduce perineal wound infection in abdominoperineal excision of the rectum. Acta Chir Scand 154(10):589-592

25. Sachweh D (1988) The local application of antibiotics in softtissue surgery. Reconstr Surg Traumatol 20:63-72

26. Chang WK, Srinivasa S, MacCormick AD et al (2013) Gentamicin-collagen implants to reduce surgical site infection: systematic review and meta-analysis of randomized trials. Ann Surg 258(1):59-65

27. Bullard KM, Trudel JL, Baxter NN et al (2005) Primary perineal wound closure after preoperative radiotherapy and abdominoperineal resection has a high incidence of wound failure. Dis Colon Rectum 48(3):438-443

28. Schwenk W, Haase O, Neudecker J et al (2005) Short term benefits for laparoscopic colorectal resection. Cochrane Database Syst Rev 3:CD003145

29. Wiatrek RL, Thomas JS, Papaconstantinou HT (2008) Perineal wound complications after abdominoperineal resection. Clin Colon Rectal Surg 21(1):76-85

30. Goldsmith HS, Griffith AL, Kupferman A et al (1984) Lipid angiogenic factor from omentum. JAMA 252(15):2034-2036

31. Walker FC, Rogers AW (1961) The greater omentum as a site of antibody synthesis. Br J Exp Pathol 42:222-231

32. Terranova O, Sandei F, Rebuffat C et al (1979) Management of the perineal wound after rectal excision for neoplastic disease: a controlled clinical trial. Dis Colon Rectum 22(4):228-233

33. Anderin C, Martling A, Lagergren J et al (2012) Short-term outcome after gluteus maximus myocutaneous flap reconstruction of the pelvic floor following extra-levator abdominoperineal excision of the rectum. Colorectal Dis 14(9):1060-1064

34. Hurwitz DJ (1988) The distal gluteus maximus advancement musculocutaneous flap for coverage of trochanteric pressure sores. Ann Plast Surg 20(2):198-200

35. Peterson SL, Stranahan PL, Schmaltz D et al (2002) Comparison of healing process following ligation with sutures and bipolar vessel sealing. Surg Technol Int 10:55-60

36. Showalter SL, Kelz RR, Mahmoud NN (2013) Effect of technique on postoperative perineal wound infections in abdominoperineal resection. Am J Surg 206(1):80-85

37. Stemberger A, Grimm H, Bader F et al (1997) Local treatment of bone and soft tissue infections with the collagen-gentamicin sponge. Eur J Surg Suppl 578:17-26

38. Nelson RL, Glenny AM, Song F (2009) Antimicrobial prophylaxis for colorectal surgery. Cochrane Database Syst Rev 1:CD001181

39. Song F, Glenny AM (1998) Antimicrobial prophylaxis in colorectal surgery: a systematic review of randomized controlled trials. Br J Surg 85(9):1232-1241 